\title{
KEY DIRECTIONS IN CHANGES FROM STEELWORKS 3.0 TO STEELWORKS 4.0 WITH ANALYSIS OF SELECTED TECHNOLOGIES OF DIGITALIZING THE STEEL INDUSTRY IN POLAND
}

\author{
Bożena GAJDZIK \\ Silesian University of Technology
}

\begin{abstract}
:
The publication is part of a new trend in popularizing Industry 4.0. The primary objective is to present the key directions in the transformation of the steel industry from steelworks 3.0 to steelworks 4.0. The work was based on a literature review and data analysis on steel 4.0 technologies. The analytical part of the thesis was prepared on the basis of the Polish steel sector (sections from the classification of economic activities: 24 and 25). On the basis of the literature study, a thesis was formulated about the need to digitize processes in enterprises heading for Industry 4.0. The application of selected technologies (ICT) in the Polish steel sector (percentage of companies using the analyzed technologies in the total number of enterprises in the sector) constitutes the scope of the research. Further research will be carried out in the area of digitization development in steel Industry toward steel 4.0
\end{abstract}

Key words: steelworks 4.0, Industry 4.0, transformation

\section{INTRODUCTION}

In recent years, the global economy has been dominated by the development of Industry 4.0, which revolutionizes the way industry functions in terms of technology. New technologies (innovations) are the basis for building the competitiveness of industries, industries (branches) and enterprises. There is no clear definition of Industry 4.0 in the literature. The development of this concept is carried out by innovative technologies, new methods of work organization and new ways of business management. Industry 4.0 uses intelligent machines, computer simulations, augmented reality, autonomous robots and other technologies to design products and implement production processes. Industry 4.0 includes big data analysis, Internet of Things (IoT), cyber security and cloud computing [1, 2 , 3]. Industry 4.0 changes the current perception of production processes and the role of human at work. Human participates in the creation and operation of Cyber Physical Systems [4]. Employees co-create new technologies and are specialists operating in cyberspace [5]. Humans need to acquire digital skills, which are those that facilitate the understanding, operation, and management of digital environments. Moreover, human skills have been pointed out to every level of the H-CPS architecture, i.e., sensation, cognitive, hard, etc. [6].
The implementation of the fourth generation technology requires large financial resources in return for which companies expect economic benefits, e.g. a strong positive effect on process efficiency, more efficient interaction between customers and suppliers, product improvements, substantial reductions in energy demand or related emissions [7, p.13]. Industry 4.0 creates Economy 4.0. Economies and industries work together. In industry, smart factories are created that function in intelligent surroundings. Smart surroundings are created (built, shaped) by many industrial sectors, such as: smart steel production, smart energy network, smart cities, smart transport, smart houses, intelligent healthcare, intelligent/smart farming, etc.

For Industry 4.0 to develop, companies and even entire industrial sectors must be open to new technologies. The implemented technological investments in industrial sectors are an area of research. For the successful implementation of the Industry 4.0 concept, it is necessary to analyse changes in individual industrial sectors.

In this publication, the research area is the development of the steel sector in Poland. The topic of Industry 4.0 in this sector is being studied by the European Commission [8]. The spatial scope of the research is the steel industry in the EU. The Polish steel sector, which is the area of re- 
search in this publication (PKD/Polish Classification of Activities/sections: (24) metal producers and (25) metal products), is part of the EC research. The main purpose of this publication is to present the key directions of development of the steel industry in Poland. The paper formulated the following research questions: What are the key directions of changes in steelworks transforming to steelworks 4.0? What is the contribution of digitization to the development of the steel sector in Poland? With regard to the transformation process, the thesis was adopted that the digitization of the steel sector (IC Technologies) is an important component of the transformation of steel producers and steel products to Steel Industry 4.0. Research questions were answered through a literature review and sector analysis.

\section{INDUSTRY 4.0 IN ECONOMIES AND BUSINESS - LITERA- TURE REVIEW}

The technologies of industries are changing in the globalization of economies and the development of electronics and ICT. Electronic economy means the implementation of economic processes using digitization within enterprises and between: Business and Business (B2B), Business and Customers (B2C), Customers and Customers (C2C) and business to human (B2H). Teleinformatization covers telecommunications and IT infrastructure. The Internet and information technologies are changing business in many areas, including: production, purchasing, delivery, servicing, communication, marketing and cooperation. Enterprises in Industry 4.0 are looking for authenticity, emphasize their individuality and innovation. Mobile technologies are becoming the link between the traditional world, mobile networks and the Internet. Modern information technologies facilitate the establishment of new business relationships and the creation of new business models $[9,10]$. The era of digital economy and ICT technologies (the development of Industry 4.0 is also influenced by $5 \mathrm{G}$ technologies [11]) influence the shape of global relations, competitive advantage and shape new opportunities for development and cooperation in the global space [12].

Industry 4.0 appeared in 2011 and has a strong influence on the shape of industry in Europe and the world. Industry 40 is becoming more and more popular. Industry 4.0 introduces leading IT solutions in many areas of production, enables the creation of personalized products and the creation of new structures of connections in value chains. New forms of factories called smart appear in Industry 4.0. Factories test the latest technologies to create value for 4.0 customers with their participation, e.g. the customer participates in product design [13].

In McKinsey Company report [14] provides examples of the forms of organization. The implementation of Industry 4.0 technologies contributes to the creation of: smart-automated and robotized plants, digital mass-individualization factories called also customer-centric plants, e-plans in a box, mobile modular factories or hand made with digital touch. Gajdzik et al. [15] emphasize that the implementation of Industry 4.0 technology is carried out in stages in manufacturing companies. Industry 4.0 is entering companies gradually. The investment projects of enterprises are implemented in segments (modular) in selected areas of their activity. The selectivity of implementing technological solutions occurs both in manufacturing companies and in individual industries. There are industries where technological progress is realized faster and easier, as well as slow ones. The first group includes industries such as food, clothing, and household appliances. The second group includes, for example, metallurgy, mining, fuel and energy industries. The ways of implementing Industry 4.0 in enterprises have not yet been described in a comprehensive and concise manner. The implementation of Industry 4.0 in companies requires changes in both strategy and business operations. According to Cellary [16] 4.0 technologies used in factories will create cooperation chains between factories (intelligent or not) and will produce intelligent products and digital services for customers in intelligent environments. A significant challenge for smart factories is the creation of cyber-physical systems with high autonomy (self-reliance). Cyber-Physical Systems (CPSs) are integrations of computation, networking, and physical processes. Embedded computers and networks monitor and control the physical processes, with feedback loops where physical processes affect computations and vice versa. CPS integrates the dynamics of the physical processes with those of the software and networking, providing abstractions and modeling, design, and analysis techniques for the integrated whole $[17,18$, 19].

Built systems (CPSs) with full automation and robots replace human work (manual activities of employees). Systems are well suited to the global, interconnected realtime economy. Modern technologies and machines are based on artificial intelligence and machine learning. Such technologies allow to precisely control production, take care of its quality, improve safety in the workplace, and rationally manage resources [20]. Human collaborates with CPS (and he is a part of the systems) - currently, the right balance is being sought between autonomous and self-organizing cyber-physical systems and the role of people (employees) in these systems (Industry 5.0) [21]. The transformation of companies to CPS will require a significant change in employee skills, organizational structures, leadership mechanisms and corporate culture. To keep up with the pace of the technological revolution, employers should completely change organizational structures, create talent management systems and use human resource management strategies embedded in the corporate strategy [22]. Human is located in the CPS. Romero et al. (2015) [23] and (2016) [24] emphasize the need for a symbiosis between man and new technologies. These authors proposed the introduction of the human factor into cyber-physical systems. The new system construction was called the Human Cyber-Physical System (H-CPS). Knowledge and creativity will remain the exclusive domain of humanity. According to Wolter et al. [25] economy 4.0 requires workers with skills: systemic thinking, reasoning and creativity. Only such people, combining 
economic and managerial knowledge with IT technical knowledge, will be able to cooperate with computer systems and robots controlled by artificial intelligence in conditions of dispersion, diversity and uncertainty [25]. Personal predispositions (skills of workers) and organizational culture must be re-analyzed in the light of the requirements of new skills and the need to attract and maintain adequate human capital in smart factories [26]. As indicated by V. Terziyan, S. Gryshko and M. Golovianko (2018) [27] the era of Industry 4.0 has started. Industry 4.0 is an opportunity for a vision of the company's functioning, product production, service provision, asset management, business, talent management and HR (Human Relations). A.C. Pereira and F. Romero (2017) [28, p.1213] add that the implementation of Industry 4.0 technology in companies will create a new value chain, improve production and engineering processes, improve the quality of products and services, optimize relations between customers and organizations, transform the current work environment in a cyber-physical environment. The results of all these are economic benefits in the areas of: productivity, quality, precision (accuracy), personalization, intensification, optimization etc.

In companies where the end product is, for example, electricity, chemicals or fuels, you gain more control over the processes and increase energy efficiency. In the case of discrete and hybrid production, e.g. car production, food $\&$ beverage, the changes allow for better adaptation of products to individual customer needs (personalization) and shortening of delivery times, thanks to flexible adjustment of production scale in factories located in different countries of the world [29]. Industry 4.0 is a concept that has been functioning in the economic space only since 2011 and there will be measurable effects in enterprises in 2030 (researchers' predictions, e.g. Neef, predictions for the steel industry) [7]. Changes are determined by the degree of development of economies and industries in individual countries. Nevertheless, the adaptation of enterprises to the new requirements of the fourth industrial revolution is necessary. There is no turning back from the transformation that has begun.

\section{KEY DIRECTIONS FOR INDUSTRY 4.0 IN THE STEEL SEC- TOR}

\section{Transformation of the steelworks into Industry $\mathbf{4 . 0}$}

Steel mills are increasingly using Industry 4.0 technologies to improve steel production. Industry 4.0 technologies have more advanced functions than traditional technologies. One of the most important features of Industry 4.0 technology is production optimization. In the steel sector, Industry 4.0 technologies are used to implement key processes, e.g. pig iron and steel production, rolling, loading handling. "Industrie 4.0", digitalization, Internet of Things and cloud computing are topics dominating current discussions and strategies in steel industry. For years, steelworks has developed strategies of digitalization. Digitalization is not new but now (it was realized in third industrial revolution) but now the key question is: "Where can digitalization help the steelworks achieve the above mentioned goals better - in a more sustainable and value adding way?" Plant operators often first think of what is referred to as the "smart steel factory", which would be able to produce steel intelligently and largely autonomously. The smart factory is characterized by the networking of activities performed by man and machine in dynamic production processes which will optimize themselves in real time taking into account the complete value chain. Digital technologies and Big Data with Cloud Computing enable steel mills to build cyber-physical systems. Digitization is considered to be a prerequisite for the steel transformation into Industry 4.0 [30]. From the beginning of the 90s, intensive projects of digitization of the steel industry were implemented in many countries around the world. Gajdzik and Wolniak [31, 32] in their papers presented cases studies about digitalization in steel industry. Here's what they found [31, 32]:

- the beginning of the intensive digitization of the steel industry in the world begins in the 1990s, in Poland it begins at the beginning of the second decade of this century, the Polish steel industry is gradually implementing digital technologies in production processes (the increasing polarization of the Industry 4.0 concept makes it easier for steel mills to implement high technologies), there are segmental (in various areas of activity) investment projects for digital technologies (cases studies: ArcelorMittal, Thyssenkrupp, Tata Steel Group),

- digital technologies in steel mills monitor the work of selected production sections and/or support basic technological devices (control parameters, control the operation of machines) the largest (key) processes and technologies, e.g. a blast furnace is supervised and controlled using IT systems, devices in steel plants and in rolling mills are equipped with sensors that provide data on the course of the process and facilitate their control, technologies with sensors create production networks, e.g. Blast Furnace Network and improve maintenance (TPM) [33],

- mills use key (basic) IC process support systems, the popular ones include Enterprise Resource Planning (ERP), Manufacturing Execution System (MES), Customer Relationship Management (CRM), key systems: ERP and MES, provide data on the operation of machines, products and production systems creating an image (maps) of the connection systems inside the steelworks,

- IC systems, such as: ERP, CAx, documentation management, project management, production planning and scheduling, Business Intelligence (data analysis and reporting), or comprehensive SAP and other solutions are integrated into the integrated IT and computer environment of steel companies,

- collaborative networks are created within strong capital groups and between steel producers and steel user markets (e.g. cooperation in building cyberspace between the steel sector and the automotive sector), 
particular gropus are participants of knowledge for develoment of value chain in the sector (e.g. according to SECI model) [34, 35, 36];

- digital technologies (e.g. loT) enable steel mills to reduce indirect links (the interactive nature of relations, e.g. with consumers and contractors (the basic instrument of Supply Chain Management, for example, is the consistent mapping of the production and material flows and the complete order handling process, including the customer order, the manufacturing order and the suppliers).

The process of transforming steel mills into Industry 4.0 must be consistent with the conditions of the steel industry. IoT and new technologies, through dynamic configuration of production processes, are conducive to meeting the key principles of sustainable production [37]. Sustainable steel production is a key strategic goal for the steel sector. The green economy is strongly related to the production of steel. In the process of transforming the steel sector (steelworks) into Industry 4.0, a balance must be strike between the technologies and their environmental impacts. Ecological aspects in the steel sector have been and are a priority for the development of this industry [38, 39]. Metallurgical investments receive support from Best Available Technology (BAT) ${ }^{1}$. The key measures of the smelters' environmental impact are: dust and gas emissions, wastewater discharges and solid waste. The interactions of the steelworks with the environment are conditioned by the strength of the negative and positive impact of the steelworks on the environment [40,41]. Investments made in recent years have reduced the arduousness of the steel industry. Technological innovation is woven into sustainability [42].

Steel production is very energy-intensive, hence one of the key ecological aspects and, at the same time, challenges for Industry 4.0 technology is energy intensity. Gajdzik and Sroka [43], and Wolniak et. al. [44] present models of energy intensity in relations to investment in Polish steel industry. The conclusion from the presented models is as follows: technological investments (in the transformation process from steelwork 3.0 to steelworks 4.0 ) reduce the energy intensity in steel production. In the pursuit of the steel sector towards Industry 4.0, sustainable development projects are implemented, such as: Circular Economy (CE), Carbon Direct Avoidance (CDA) - based metallurgy and electricity-based metallurgy; Smart Carbon Usage (SCU) with Process Integration and Carbon Valorisation/CCU; Carbon Capture and Storage CCS (not included in SCU, CDA or CE). Among the indicated projects, two centers on the Polish steel market are of major importance for the implementation of projects. The first is located in Dąbrowa Górnicza DG - ArcelorMittal Poland, the second in Ostrowiec Świętokrzyski - Celsa Huta Ostrowiec. These two mills are the beneficiaries of the projects, respectively: Dabrowa Górnicza: DG CDA, Ostrowiec Świętokrzyski: Energy Efficient EAF, PSWD, Renevable Energy (Source: Eurofer, 2021) [45].
In addition to environmental challenges, a significant challenge of Industry 4.0 technology for the steel sector is the improvement of work safety in steel mills. Work in steel mills is classified (in Polish law) as difficult. Accidents at work are strongly related to hard working conditions (high temperature, dust, gases) [46]. Work accidents in this sector are caused by extremely difficult and demanding working conditions. Very high temperature, noise or dust. Analyzing the period from 2009 to 2018, the authors found that the number of people injured in accidents in the steel sector was 967 injured per year [47]. Apart from the causes not controlled by humans (explosion, fire, ignition of materials), there are technical reasons (defect of the material factor and poor state of security) and human (disregarding the hazard, insufficient concentration of attention, improper use of limbs in the danger zone, surprise by an unexpected event, improper working methods, non-compliance with health and safety regulations, failure to use safety footwear by the employee, performing activities without removing the risk, other (e.g. carelessness, trips) $[48,49]$. Workers in the following positions are particularly exposed: welders, rolling mills, and foundry workers $[48,49]$. Modern technology is increasingly replacing employees in conditions that are difficult for their health. Employees do not have to work in a hazardous work environment - in such an environment, independent robots work. Industry 4.0 technologies can contribute to reducing the accident rate, if they are applied where working conditions are particularly dangerous for humans or if it helps to control human work and production processes (process optimization), reducing the risk of accidents through information functions, blocking incorrect activities human or even stopping processes to prevent failures, etc. [50]. The modern technology of Industry 4.0 is intertwined with building a culture of work safety in steel 4.0 [51].

Based on the above, it can be concluded that digitization, sustainability and security are key components of the transformation of steel mills to Industry 4.0. I call these dependencies the triad of transformation from steelwork 3.0 to steel works 4.0 (Fig. 1 ).

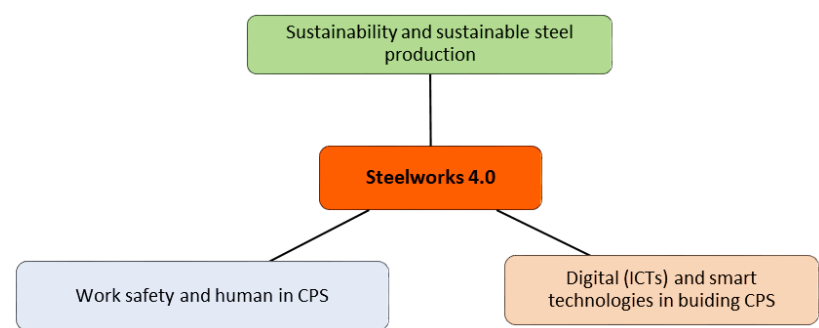

Fig. 1 The triad of transformation from steelworks 3.0 to steelworks 4.0

Selected solutions in the transforming of steelworks into Industry $\mathbf{4 . 0}$

Along with successive industrial revolutions, steel mills reach new levels of development. There is no universal procedure for implementing Industry 4.0 technology in

\footnotetext{
${ }^{1}$ BAT - the name from a document of EU about IPPC
} 
the steel sector. Currently, mills are at the 3.0 level of development with elements of smart technology. Quoting from Neef et al. [7] the changes in steel mills in the pursuit of Industry 4.0 are stretched over time and it takes another decade to be strongly visualized in the steel industry. Changes are introduced modularly. The road of steel mills to Industry 4.0 is in line with the adopted policy for the development of the steel sector in the EU until 2030. The transformation of steel mills to Industry 4.0 begins with digitization. Quoting from Peters (2017) [30] “Digitalisation is a pre-condition for Industry 4.0, but Industry 4.0 is much more than digitalisation!" Peters $[30,52]$ gives examples of technological solutions for the steel sector transforming to Industry 4.0 (Table 1). Digital technologies and IC systems (e.g. ERP, MES) integrate production processes with other activities in steel plants. According to Govender et al. [53] digital technologies create the frameworks in steel industry. Neef et al. [7] presents the key directions of changes, which are also dominated by digitization and automation. Each of these publications emphasizes the gradation of changes and the importance of digitization in the transformation of the steel industry to the level of Industry 4.0. Examples of technological solutions used in steel mills proposed by the authors (Peters, Neef et al., Govender et al.) are presented in Table 1.

Table 1

Toward smart steel industry - a concept of technological solutions

\begin{tabular}{|c|c|}
\hline Peters $[30,52]$ & 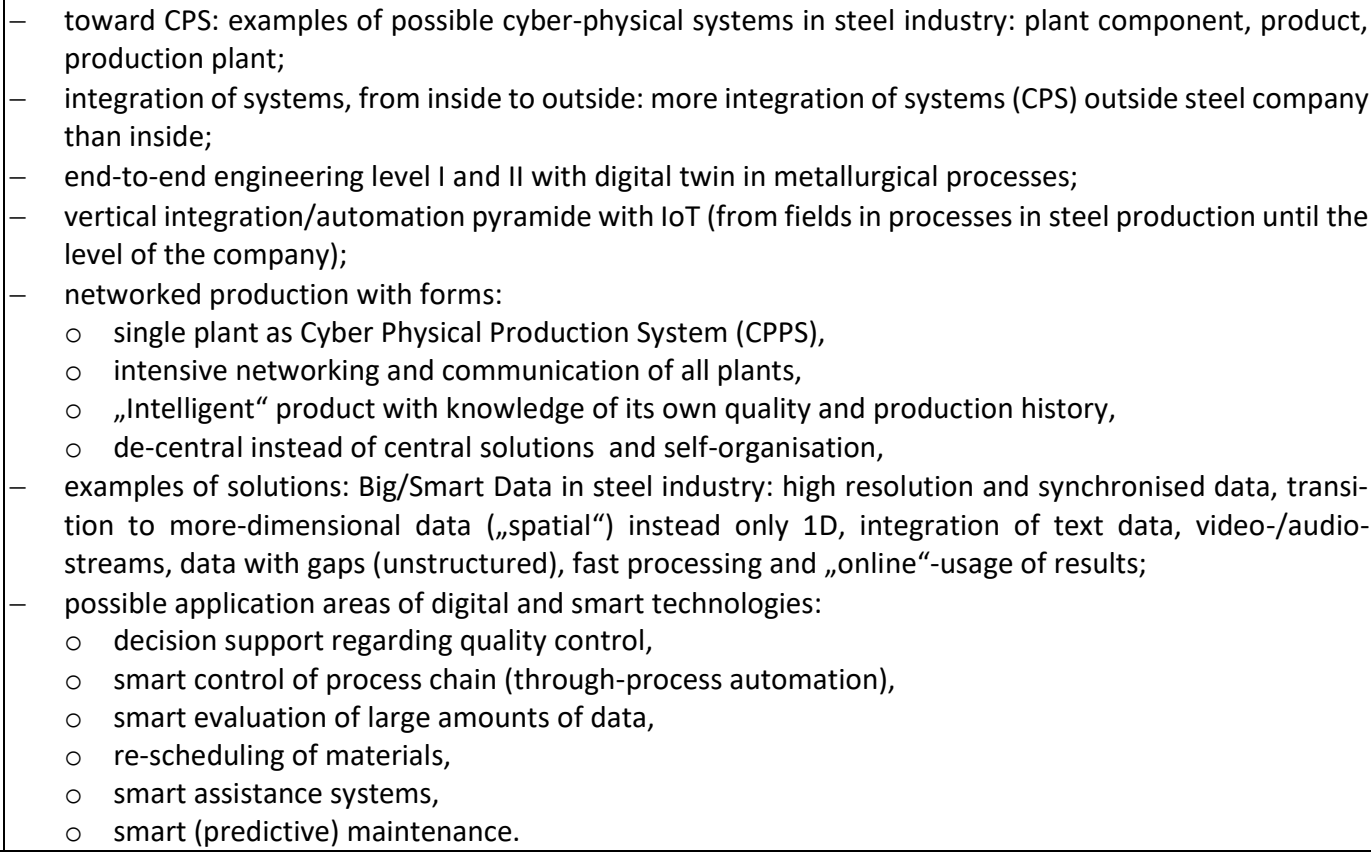 \\
\hline Govender et al.[53] & 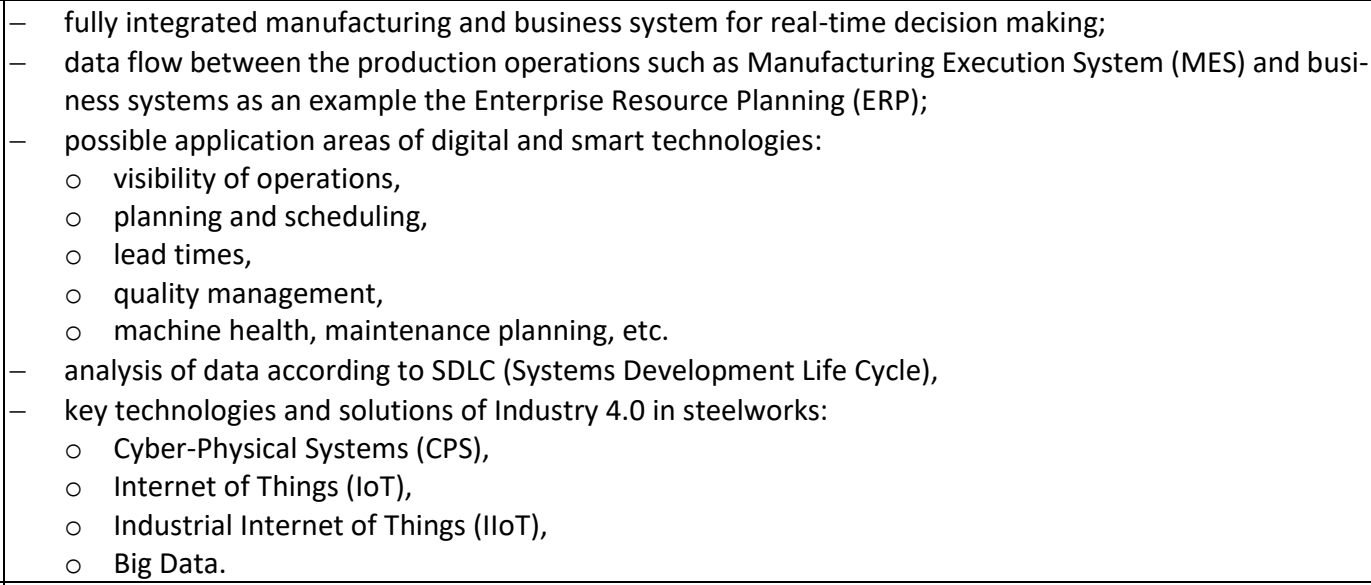 \\
\hline Neef et al. [7] & $\begin{array}{l}- \\
\text { key directions of changes: digitalization and automation: e.g. add sensors or data-driven process con- } \\
\text { trol; } \\
\text { - } \quad \text { two levels of changes: strategic and operational (technologies of Industry } 4.0 \text { are a part of strategical } \\
\text { plans in steelworks), } \\
-\quad \text { cooperating with external partners during implementing of digital and smart technologies in steelworks; } \\
-\quad \text { forms of changes: phasing (modularity), sequencing of changes in steelworks; } \\
-\quad \text { "downstream" production areas: } \\
\quad \circ \quad \text { rolling and coating/finishing in the technical domain, } \\
\text { o the interaction with customers in the organizational domain. } \\
-\quad \text { a focus on economic benefits during implantation of new technologies of Industry 4.0. }\end{array}$ \\
\hline
\end{tabular}




\section{Analyses of selected IC technologies using in the steel in- dustry}

The use of IC technology in steel industry was presented on the basis of statistical data. The scope of the analysis covered producers of metals and finished metal products (according to PKD: section 24 and section 25). The data published by the Central Statistical Office [54] was used for the analysis. The scope of the analysis covered annual data (prepared for 2019). The following tables were used:

- enterprises using different types of internet connections in 2019;

- enterprises purchasing cloud services in 2019;

- enterprises conducting data analysis, the so-called big data in 2019;

- enterprises using 3D printing in their activities in 2019;

- enterprises using robots in their activities in 2019;

- enterprises applying ICT security measures in 2019.

In 2019, 5,715 enterprises were registered in the analyzed sectors (enterprises operating in total accounted for $100 \%$ in the analysis). The results of the analysis are presented in Fig. 2.

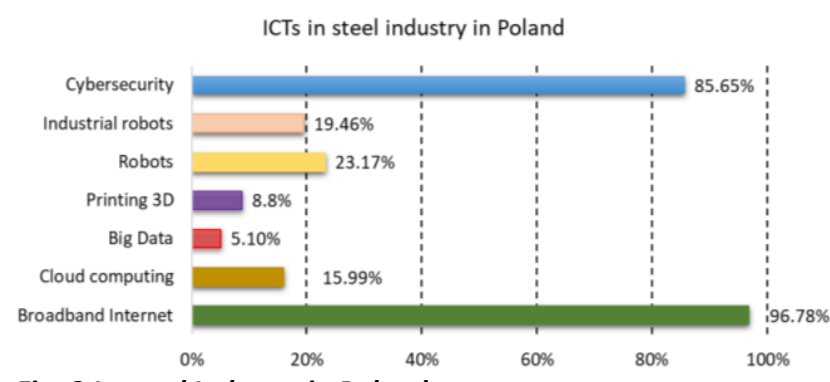

Fig. 2 In steel Industry in Poland

Source: based on data from GUS for 2019.

Conclusions from the analysis:

- In 2019, $96.87 \%$ of producers of metals and finished metal products had access to broadband Internet out of 5,715 companies. Companies use the Internet through DSL or other fixed broadband connections (e.g. cable TV network, fiber optic network); mills also use the mobile form of the Internet via mobile devices - cellular telephone networks.

- Out of $96.87 \%$ of producers of metals and finished metal products with access to the Internet (broadband), $15.99 \%$ buy cloud services, including the most popular forms:

- e-mail services (11.33\%),

- office software is purchased through the cloud (9.5\%),

- storing files (documents) in the cloud (8.12\%).

- $5.1 \%$ of enterprises in sectors 24 and 25 will create Big Data centers in the areas of:

- communication between devices (M2M machines), digital sensors, RFID tags etc.,

- acquired geolocation data from mobile devices (e.g. from mobile devices using cellular telecommunications networks, from wireless connections or GPS),
- data generated by social media (e.g. by social networks, blogs, websites used to exchange multimedia information),

- other sources (e.g., transactional data, open data); machine learning; processing or natural language generation (NLP, NLG);

- $8.8 \%$ of manufacturers use 3D printing to: create prototypes or models for sale, create prototypes or models for their own use, create goods for sale, excluding prototypes or models (e.g. molds, tools, parts, semifinished products, etc.), create goods used in the production process excluding prototypes or models (e.g. molds, tools, parts, semi-finished products, etc.);

- $23.17 \%$ of producers in steel industry use robots, including: $19.46 \%$ use industrial robots; examples of application areas:

- for protection, observation, supervision, e.g. with the use of autonomous drones,

- transport of people or objects, e.g. with the use of autonomous vehicles,

- for cleaning or garbage collection,

- for work in the warehouse, e.g. stacking pallets,

- for assembly work,

- about customer service,

- assembling the structure or repairing damage.

- $85.65 \%$ of enterprises applying ICT security measures: examples of activity:

- strong password authentication,

- ongoing software updates,

- biometric user identification and authentication, data, document and e-mail encryption,

- data backup and transfer to other locations,

- enterprise network access control,

- use of VPN connections,

- storing logs for analysis after an incident related to ICT security,

- ICT risk assessment,

- performing ICT security tests,

- conducting information system security audits.

\section{CONCLUSIONS}

All industrial revolutions have common features that distinguish them by technical changes. The third industrial revolution starts with ICT and the fourth one creates smart technologies. Revolution 4.0 is associated with a change in the approach to production from the analysis of the conditions for the development of Industry 4.0 (factors influencing the development of Industry 4.0 technology) to technological investments changing the existing forms of production organization towards CPS. Steelworks with digital and smart technologies (over time) will become smart steelworks, and their cooperation with other companies in the chain will create a smart value chain. Entering the era of the fourth industrial revolution is a challenge for the Polish steel industry. Scientific research and statistical data confirm that intensified activities for the development of the Industry 4.0 concept are already being taken in steel mills. When analyzing the data on ICT in Polish steel industry, it can be noticed that there 
are already companies implementing the Industry 4.0 concept and, most importantly, they are starting to take specific actions (the examples of technological solutions in the paper cited above).

\section{ACKNOWLEDGEMENTS}

Payment by The Department of Industrial Informatics, Silesian University of Technology supported this work as a part of Statutory Research BK: 11/040/BK_21/0023.

\section{REFERENCES}

[1] K. Schwab, The Fourth Industrial Revolution, Davos: World Economic Forum, 2016.

[2] H. Kagermann, J. Helbig, A. Hellinger, W. Wahlster, Recommendations for Implementing the Strategic Initiative INDUSTRIE 4.0: Securing the Future of German Manufacturing Industry, Final Report of the Industrie 4.0 Working Group, Forschungsunion, 2013.

[3] M. Hermann, T. Pentek, B. Otto, "Design Principles for Industrie 4.0 Scenarios", in $49^{\text {th }}$ Hawaii International Conference on System Sciences (HICSS), IEEE, 2016, pp. 3928-3937.

[4] D. Romero, J.,Stahre, T. Wuest, O. Noran, P. Bernus, Å. Fast-Berglund, D. Gorecky, "Towards an Operator 4.0 Typology: A Human-Centric Perspective on the Fourth Industrial Revolution Technologies", in Proceedings of the International Conference on Computers and Industrial Engineering (CIE46), Tianjin, China, Vol. 11 (29-31), pp. 111, October 2016.

[5] P. Wittbrodt, I. Łapuńka, "Przemysł 4.0 - wyzwanie dla współczesnych przedsiębiorstw produkcyjnych", in: Innowacje w Zarzqqdzaniu i Inżynierii Produkcji, R. Knosala (ed.), t. 2, Oficyna Wydawnicza Polskiego Towarzystwa Zarządzania Produkcja, Opole 2017, pp. 793-799.

[6] E. Flores, X. Xu, Y. Lu, "Human Cyber-Physical Systems: A skill-based correlation between humans and machines" in, $16^{\text {th }}$ IEEE International Conference on Automation Science and Engineering (CASE) August 20-21, 2020, pp. 13131318.

[7] Ch. Neef, S. Hirzel, M. Arens, Industry 4.0 in the European Iron and Steel Industry: Towards an Overview of Implementations and Perspectives Working document, Fraunhofer Institute for Systems and Innovation Research ISI, Karlsruhe, Germany, 05. September 2018.

[8] Blueprint "New Skills Agenda Steel": Industry-driven sustainable European Steel Skills Agenda and Strategy (ESSA).

[9] S. Grabowska, Model biznesu 4.0. Architektura, tworzenie wartości, ocean konkurencyjności i efektywności, Toruń: TNOiK, 2021.

[10] A. Jabłoński, "Twórczy model biznesu w koncepcji gospodarki sieciowej". Studia i Prace Kolegium Zarzqdzania i Finansów. Zeszyty Naukowe, vol. 162, pp. 175-192, 2018.

[11] S.K. Rao, R. Prasad, "Impact of $5 \mathrm{G}$ Technologies on Industry 4.0", Wireless Personal Communications, Vol. 100, No. 1, pp. 145-159, 2018.

[12] R. Niedbał, A. Wrzalik, A. Sokołowski, “Czwarta rewolucja przemysłowa jako wyzwanie utrzymania konkurencyjności przedsiębiorstwa", Marketing i Rynek, No 7, pp. 557-570, 2017.

[13] V. Ramaswamy, "It's about human experience... and beyond, to co-creation", Industrial Marketing Management, No. 40, pp. 195-196, 2011.
[14] Mc Kinsey, Industry 4.0 How to navigate digitization of the manufacturing sector. 2015. Retrivered from: http://www.forschungsnetzwerk.at/downloadpub/mck_i ndustry_40_report.pdf. 2015

[15] B. Gajdzik, S. Grabowska, S. Saniuk, "A Theoretical Framework for Industry 4.0 and Its Implementation with Selected Practical Schedules", Energies, Vol. 14(1), 129, 2021; https://doi.org/10.3390/en14010129.

[16] W. Cellary, "Przemysł 4.0 i Gospodarka 4.0", Biuletyn PTE Part I: Olimpiada wiedzy ekonomicznej, No. 3(86), August 2019.

[17] J. Lee, B. Bagheri, H. Kao, "Research Letters: A CyberPhysical Systems architecture for Industry 4.0-based manufacturing systems", Manufacturing Letters, 3, pp. 1823, 2015.

[18] N. Jazdi, "Cyber Physical Systems in the Context of Industry 4.0," in IEEE International Conference on Automation, Quality and Testing, Robotics, 2014, pp. 1-4.

[19] Y. Liu, Y. Peng, B. Wang, S. Yao, Z. Liu, "Review on cyberphysical systems", in IEEE, CAA. J. Autom. Sin., Vol. 4 (1), pp. 27-40, 2017.

[20] B Ślusarczyk, "Potencjalne rezultaty wprowadzania koncepcji Przemysłu 4.0 w przedsiębiorstwach" Przeglad Organizacji, No 1 (948), pp. 4-10, 2019, https://doi.org/10.33141/po.2019.01.01.

[21] Industry 5.0 Towards a sustainable, human centric and resilient European industry, p. 14. European Commission, Brussels, Manuscript completed in January 2021, Available online: https://op.europa.eu/en/publication-detail//publication/aed3280d-70fe-11eb-9ac901aa75ed71a1/language-en/format-PDF/source-search.

[22] M.K. Wyrwicka, B. Mrugalska, "Industry 4.0 - Towards Opportunities and Challenges of Implementation", in 24th International Conference on Production Research, pp. 382-387, 2017.

[23] D. Romero, O. Noran, J. Stahre, P. Bernus, Å. FastBerglund, "Towards a Human-Centred Reference Architecture for Next Generation Balanced Automation Systems: Human-Automation Symbiosis", Collab. Hyperconnected World, Vol. 460, pp. 556-566. 2015, doi:10.1007/978-3-319-22759-7_64.

[24] D. Romero, P. Bernus, O. Noran, J. Stahre, Å.F. Berglund, "The operator 4.0: Human cyber-physical systems \& adaptive automation towards human-automation symbiosis work systems", in IFIP Advances in Information and Communication Technology; Springer: New York, NY, USA, Vol. 488, pp. 677-686, 2016.

[25] M.I. Wolter, A. Mönnig, M. Hummel, E. Weber, G. Zika, R. Helmrich, T. Maier, C. Neuber-Pohl, "Economy 4.0 and its labour market and economic impacts. Scenario calculations in line with the BIBB-IAB qualification and occupational field projections", IAB Forschungsbericht, Vol. 13 , 2016, http://doku.iab.de/forschungsbericht/2016/ fb1316_en.pdf (15.07.2019).

[26] S. Kergroach, "Industry 4.0: New Challenges and Opportunities for the Labour Market", Foresight and STI Governance, Vol. 11, No. 4, p. 6, 2017.

[27] V. Terziyan, S. Gryshko, M. Golovianko, "Patented Intelligence: Cloning Human Decision Models for Industry 4.0", Journal of Manufacturing Systems, Vol. 48, pp. 204217, 2018.

[28] A.C. Pereira, F. Romero, "A Review of the Meanings and the Implications of the Industry 4.0 Concept", Procedia Manufacturing, Vol. 13, pp. 1206-1214, 2017. 
[29] M. Młody, "Personalizacja produktów a Przemysł 4.0 ocena implementacji nowoczesnych technologii w przemyśle produkcyjnym z perspektywy konsumentów", (Products Personalization and Industry 4.0 - Evaluation of the Implementation Validity of Modern Technologies in the Manufacturing Industry from the Perspective of Consumers) Ekonomika i Organizacja Przedsiębiorstwa, No. 3, pp. 62-72, 2018.

[30] H. Peters, How could Industry 4.0 transform the Steel Industry? Presentation at Future Steel Forum, Warsaw, Poland, 14.-15.6.2017.

[31] B. Gajdzik, R. Wolniak, "Digitalisation and Innovation in the Steel Industry in Poland - Selected Tools of ICT in an Analysis of Statistical Data and a Case Study". Energies, Vol. 14, 334, 2021, doi10.3390/en14113034.

[32] B. Gajdzik, R. Wolniak, "Transitioning of Steel Producers to the Steelworks 4.0 - Literature Review with Case Studies", Energies, Vol. 14, 4109,2021. https://doi.org/10.3390/en14144109.

[33] B. Gajdzik, "Autonomous and professional maintenance in metallurgical enetrprise as activirties within total productive maintenance", Metalurgija, Vol. 53, No. 2, pp. 269-272, 2014

[34] I. Nonaka, H. Takeuchi, The knowledge-creating company. New York: Oxford: Oxford University Press, pp. 57, 62, 71, 1995.

[35] P.S. Adler, "Comment on I. Nonaka. Managing innovation as an organizational knowledge creation process", in J. Allouche and G. Pogorel, (Eds), Technology management and corporate strategies: a tricontinental perspective. Amsterdam: Elsevier, pp 110-124, 1995.

[36] K. Grzybowska, and B. Gajdzik, "SECl model and facilitation in change management in metallurgical enterprise", Metalurgija, Vo. 52, No. 2, pp. 275-278, 2013.

[37] D. Kiel, J.M. Müller, C. Arnold, K.I., Voigt, "Sustainable Industrial Value Creation: Benefits and Challenges of Industry 4.0", International Journal of Innovation Management, Vol. 21 (8), pp. 1-34, 2017.

[38] B. Gajdzik, S. Grabowska, S. Saniuk, T. Wieczorek, "Sustainable Development and Industry 4.0: A Bibliometric Analysis Identifying Key Scientific Problems of the Sustainable Industry 4.0", Energies, Vol. 13(16), 4254, 2020, https://doi.org/10.3390/en13164254

[39] B. Gajdzik, A. Wyciślik, "Assessment of environmental aspects in a metallurgical enterprise", Metalurgija, Vol. 51 (4), pp. 537-540, 2012.

[40] B. Gajdzik, "Environmental aspects, strategies and waste logistic system based on the example of metallurgical company", Metalurgija, Vol. 48(1), pp. 63-67, 2009.

[41] B. Gajdzik, "Comprehensive classification of environmental aspects in a manufacturing enterprise", Metalurgija, Vol. 51, No. 4, pp. 541-544, 2012.

[42] I. Klosok-Bazan, B. Gajdzik, J. Machnik-Słomka, W. Ocieczek, "Environmental aspects of innovation and new technology implementation in metallurgy industry", Metalurgija, Vol. 54 (2015) 2, pp. 433-436, Apr-Jun 2015.
[43] B. Gajdzik, W. Sroka, "Resource Intensity vs. Investment in Production Installations - The Case of the Steel Industry in Poland", Energies, Vol. 14, 443, 2021, https://doi.org/10.3390/en14020443.

[44] R. Wolniak, S. Saniuk, S. Grabowska, B. Gajdzik, "Identification of Energy Efficiency Trends in the Context of the Development of Industry 4.0 Using the Polish Steel Sector as an Example", Energies, Vol. 13, 2867, 2020; doi:10.3390/en13112867 www.mdpi.com/journal/energies.

[45] Eurofer, 2021, the European Steel Association, www.eurofer.eu

[46] T. Małysa, B. Gajdzik, "Research on Differentiation of Accidents at Work Considering Demographic Features of Workers in Steel Sector in Poland", Inzinerine EkonomikaEngineering Economics 2021.

[47] T. Małysa, B. Gajdzik, "Predictive models of accidents at work in the steel sector as a framework for sustainable safety", Energies, Vol. 14 iss. 1 pp. 1-20, 2021 (art. no. 129), doi: 10.3390/en14010129. Online: url: https://doi.org/10.3390/en14010129.

[48] E. Kardas, "Analiza wypadków jako ocena skuteczności działania systemu zarządzania bezpieczeństwem i higieną pracy w przedsiębiorstwie hutniczym", Prace IMZ Vol.5, pp. 20-23, 2009.

[49] J. Rut, A. Pytel, “Analiza wypadków przy pracy dla potrzeb zmniejszenia ryzyka zawodowego przykładzie wybranego przedsiębiorstwa", Prace naukowe Akademii im. Jana Długosza w Częstochowie Technika, Informatyka, Inżynieria Bezpieczeństwa, t. II, p. 345 2014, http://dx.doi.org/10.16926/tiib.2014.02.30.

[50] J. Zhou, P. Li, Y. Zhou, B. Wang, J. Zang, and L. Meng, "Toward New-Generation Intelligent Manufacturing," Engineering, Vol. 4, No. 1, pp. 11-20, 2018.

[51] K.J. Nielsen, "Improving safety culture through the health and safety organization: A case study", Journal of Safety Reserarch Vol. 48, pp. 7-17, 2014, Available from internet: https://doi.org/10.1016/j.jsr.2013.10.003.

[52] H. Peters, Application of Industry 4.0 concepts at steel production from an applied research perspective, Presentation at $17^{\text {th }}$ IFAC Symposium on Control, Optimization, and Automation in Mining, Mineral and Metal Processing, 2016.

[53] E. Govender, A. Telukdarie, M.N. Sishi, "Approach for Implementing Industry 4.0 Framework in the Steel Industry", in: 2019 IEEE International Conference on Industrial Engineering and Engineering Management (IEEM). Date of Conference: 15-18 Dec. 2019. Date Added to IEEE Xplore: 03 February 2020. Conference Location: Macao, China. DOI: 10.1109/IEEM44572.2019.8978492.

[54] GUS:https://stat.gov.pl/download/gfx/portalinformacyjny/pl/defaultaktualnosci/5497/3/19/1/ict_w_przedsiebiorstwach_2020.xIsx

\author{
Bożena Gajdzik \\ ORCID ID: 0000-0002-0408-1691 \\ Silesian University of Technology \\ Faculty of Materials Engineering \\ ul. Krasińskiego 8, 40-019 Katowice, Poland \\ e-mail: bozena.gajdzik@polsı.pl
}

